Sulastri, S., Sulistiyani, H., \& Khasanah, F. (2021). Saliva pH Between Gargling and Without Gargling

Water after Consuming Sweet and Sticky Foods. JURNAL INFO KESEHATAN, 19(1),

85-96. https://doi.org/10.31965/infokes.Vol19/ss1.466

85

Jurnal Info Kesehatan

Vol. 19, No. 1. June 2021, pp. 85-96

P-ISSN 0216-504X, E-ISSN 2620-536X

DOI: 10.31965/infokes.Vol19Iss 1.466

Journal homepage:http://jurnal.poltekeskupang.ac.id/index.php/infokes

R E S E A R C H

Open Access

\title{
Saliva pH between Gargling and without Gargling Water after Consuming Sweet and Sticky Foods
}

\author{
Siti Sulastri ${ }^{1 \mathrm{a}}$, Herastuti Sulistiyani ${ }^{1 \mathrm{~b}}$, Furaida Khasanah $^{1 \mathrm{c}^{*}}$ \\ ${ }^{1}$ Department of Dental Health, Poltekkes Kemenkes Yogyakarta, Yogyakarta, Indonesia. \\ a Email address: sitislstr7@gmail.com \\ bEmail address: herastutisulistyani@gmail.com \\ c Email address: furaida.khasanah@poltekkesjogja.ac.id
}

Received: 12 August 2020

Revised: 27 June 2021

Accepted: 29 June 2021

\begin{abstract}
Sweet and sticky foods are the main energy source for oral bacteria and are directly involved in lowering the $\mathrm{pH}$. Gargling with boiled water after every meal can speed up the $\mathrm{pH}$ of the saliva in the mouth to return to normal. The objective of this study is to determine the difference in salivary $\mathrm{pH}$ between gargling and without gargling water after consuming sweet foods in elementary school students. The research method used was quasi-experimental with pretest and posttest with control group design. The instrument in this research was a $\mathrm{pH}$ meter. The population in this study were students in grades I - V of public elementary schools in Bantul with a total population of 135. The research sample used total sampling. Analysis of the research data was conducted using the Wilcoxon test, Mann Withney and Anova Test. The results showed that the $\mathrm{pH}$ of saliva (direct gargling) of water/ 0 minutes after consuming sweet and sticky foods was before 7.53 after gargling 7.99 increased by 0.46 . The $\mathrm{pH}$ of gargling saliva 5 minutes before 7.48 after rinsing 7.63 increased 0.15 . $\mathrm{pH}$ of saliva gargling 10 minutes, that was before 7.31 after gargling 7.3 decreased by $0.18 \mathrm{pH}$ of saliva (without rinsing) water $/ 0$ minutes, which was initial $\mathrm{pH} 7.68$ to 7.55 after consuming sweet and sticky foods, decreased 0 ,13. The $\mathrm{pH}$ of saliva without rinsing with water for 5 minutes, the initial $\mathrm{pH}$ was 7.70 to 7.06 , decreased by 0.64 . The most effective gargling time on salivary $\mathrm{pH}$ was gargling water immediately 0 minutes after consuming sweet and sticky foods. The time without gargling water affecting the $\mathrm{pH}$ of saliva after consuming sweet and sticky foods was 5 minutes.
\end{abstract}

Keywords: Gargling With Water, No Rinse With Water, Saliva pH, Sweet and Sticky Food.

\footnotetext{
*Corresponding Author:

Furaida Khasanah

Department of Dental Health, Poltekkes Kemenkes Yogyakarta, Yogyakarta, Indonesia.

Email: furaida.khasanah@poltekkesjogja.ac.id

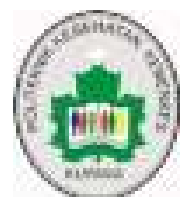

(C) The Author(s) 2021. This article is distributed under the terms of the Creative Commons Attribution 4.0 International License (http://creativecommons.org/licenses/by/4.0/), which permits unrestricted use, distribution, and reproduction in any medium, provided you give appropriate credit to the original author(s) and the source, provide a link to the Creative Commons license, and indicate if changes were made. The Creative Commons Public Domain Dedication waiver (http://creativecommons.org/publicdomain/zero/1.0/) applies to the data made available in this article, unless otherwise stated.
} 


\section{INTRODUCTION}

Dental caries can occur, one of which is caused by food/some types of dietary carbohydrates, such as sucrose and glucose fermented by certain bacteria and form acid so that the plaque $\mathrm{pH}$ decreases to below 5 within 1-3 minutes. Repeated decrease in $\mathrm{pH}$ will result in demineralization of vulnerable tooth surfaces and the caries process begins (Lestari \& Putri, 2016). Sweet and sticky foods contain carbohydrates which are the main energy source for oral bacteria and are directly involved in lowering $\mathrm{pH}$ (Jannah, et al., 2016). Gargling is one of the preventive measures for dental caries, which is the easiest and cheapest to do, so that the habit of gargling using plain water after eating sweet and sticky foods is an alternative in maintaining the $\mathrm{pH}$ of saliva so that it remains within normal limits so that it does not weaken tooth enamel (Wahyuningsih, \& Ramadhani, 2015). In the Special Region of Yogyakarta, the number of sufferers of dental and oral problems, according to the 2018 Basic Health Research, was 47.7\% higher than the national average of $45.3 \%$ of dental and oral problems (Kementerian Kesehatan, R. I., 2018).

Oktarinda (2011), stated that Saliva is one of the components that contributes to the level of acidity $(\mathrm{pH})$ of the mouth. Saliva helps the process of remineralizing small lesions on the tooth enamel layer (Kusumasari, 2012). Saliva is a thick fluid produced by the salivary glands, parotid glands, sublingual glands and submandibular glands, which are located under the tongue near the cheek muscles and near the palate. Saliva contains $99.5 \%$ water (Haryani, et al., 2016).

The results of preliminary study interviews with 10 elementary school students in Bantul, regarding gargling water after eating sweet and sticky foods, it was found that $70 \%$ of students did not rinse their mouths water after consuming sweet and sticky foods, and had many cavities, and had never been tested for salivary $\mathrm{pH}$ after consuming sweet and sticky foods. The objective of this study is to discover an effective gargling time in maintaining normal salivary $\mathrm{pH}$ after consuming sweet and sticky foods.

\section{RESEARCH METHOD}

This type of research was quasi-experimental with Pretest and Posttest with Control Group Design (Notoadmodjo, 2012). The research technique used was to test the difference in salivary $\mathrm{pH}$ between gargling and without rinsing with water after consuming sweet and sticky foods in elementary school students at minute 0 , minute 5 and minute 10 after consuming sweet and sticky foods. This research was conducted in one of the public elementary schools in Bantul, Yogyakarta. The population in this study were students in Grades I - V of State Elementary Schools in Bantul. The sample in this study used a total sampling technique of 135 respondents. The statistical tests used were Wilcoxon, Mann Withney and Anova test (Jannah et al., 2016). The inclusion criteria in this study were aged 6-12 years, had the habit of eating sweet and sticky foods, willing to be respondents, and communicative. The exclusion criteria in this study were students with teeth that had caries. This research has received approval from the ethics commission with the ethics number e-KEPK/POLKESYO/0149/VI/2019. 


\section{RESULTS AND DISCUSSION}

Table 1. Average Saliva $\mathrm{pH}$ of Respondents Gargling Water after Consuming Sweet and Sticky Foods.

\begin{tabular}{|c|c|c|c|c|c|c|c|}
\hline \multirow[t]{2}{*}{ Variable } & \multicolumn{3}{|c|}{ pH Saliva } & \multicolumn{4}{|c|}{ Wilcoxon Test } \\
\hline & Before & After & Deviation & $\mathbf{Z}$ & $\begin{array}{r}\text { Asymp. } \\
\text { Sig. }\end{array}$ & $\mathbf{A}$ & Information \\
\hline $\begin{array}{l}\text { Group } \\
\text { Directly } \\
\text { Gargling/0 } \\
\text { minutes }\end{array}$ & 7,53 & 7,99 & 0,46 & -2.856 & 0,004 & 0,05 & Meaningful \\
\hline $\begin{array}{l}\text { The group } \\
\text { of } 5 \\
\text { minutes } \\
\text { just rinsed } \\
\text { with water }\end{array}$ & 7,48 & 7,63 & 0,15 & $-1,351$ & 0,177 & 0,05 & $\begin{array}{r}\text { Not } \\
\text { meaningful }\end{array}$ \\
\hline $\begin{array}{l}\text { The group } \\
\text { of } 10 \\
\text { minutes } \\
\text { just rinsed } \\
\text { with water }\end{array}$ & 7,31 & 7,13 & 0,18 & $-1,543$ & 0,123 & 0,05 & $\begin{array}{r}\text { Not } \\
\text { meaningful }\end{array}$ \\
\hline
\end{tabular}

Table 1 shows that the $\mathrm{pH}$ value of saliva in the gargling group $/ 0$ minutes after consuming sweet and sticky foods increased the most from before consuming sweet and sticky foods, namely from 7.53 to 7.99 with a difference of 0.46 . The 10 -minute group just rinsed their mouth after consuming sweet and sticky foods. The saliva $\mathrm{pH}$ decreased from 7.31 to 7.13 with a difference of 0.18 . The Asymp. Sig (p) value of gargling directly $/ 0$ minutes was $0.004<0.05$, thus, Ho was accepted and Ha was rejected, meaning that statistically it showed that there was a significant difference in gargling directly/0 minutes before and after consuming sweet foods and attached to salivary $\mathrm{pH}$. SDN Puluhan students, meaning that there is an effect of gargling water immediately after consuming sweet foods and is attached to the salivary $\mathrm{pH}$ of SDN Puluhan students. The Asymp. Sig (p) value of gargling water 5 minutes after consuming sweet and sticky foods is $0.177>0.05$, thus, Ho is rejected and Ha is accepted, statistically means that there is no significant difference in salivary $\mathrm{pH}$ before and after consuming sweet foods attached for 5 minutes then rinsed with water, meaning that there was no effect of gargling water 5 minutes after consuming sweet foods and attached to the $\mathrm{pH}$ of the saliva of SDN Puluhan students. The Asymp. Sig (p) $\mathrm{pH}$ value of saliva gargling with water 10 minutes after consuming sweet and sticky foods is $0.123<0.05$, thus, Ho is rejected and $\mathrm{Ha}$ is accepted, statistically means that there is no significant difference in salivary $\mathrm{pH}$ before and after consuming sweet food and stick to it 10 minutes then rinse with water. It means that there is no effect of gargling with water, 10 minutes after consuming sweet food and sticking to the $\mathrm{pH}$ of the saliva of SDN Puluhan students. The group without gargling water 5 minutes after consuming sweet and sticky foods experienced the most decrease in $\mathrm{pH}$ from 7.70 to 7.06 with a difference of 0.64 . 
Table 2. Average Saliva $\mathrm{pH}$ of Respondents without Gargling Water after Consuming Sweet and Sticky Foods.

\begin{tabular}{lccccccc}
\hline Variable & \multicolumn{3}{c}{ pH Saliva } & \multicolumn{3}{c}{ Wilcoxon Test } \\
\cline { 2 - 8 } & Before & After & Deviation & $\mathbf{Z}$ & $\begin{array}{c}\text { Asym } \\
\text { p. Sig }\end{array}$ & A & Information \\
\hline $\begin{array}{l}\text { No } \\
\text { Gargling }\end{array}$ & 7,68 & 7,55 & 0,13 & $-1,147$ & 0,251 & 0,05 & $\begin{array}{c}\text { Not } \\
\text { meaningful }\end{array}$ \\
$\begin{array}{l}\text { Group/0 } \\
\text { minutes }\end{array}$ & & & & & & & \\
\hline $\begin{array}{l}\text { Group 5 } \\
\text { minutes } \\
\text { without } \\
\text { gargling }\end{array}$ & 7,70 & 7,06 & 0,64 & $-5,030$ & 0,000 & 0,05 & Meaningful \\
water. & & & & & & & \\
\hline $\begin{array}{l}\text { Group 10 } \\
\text { minutes } \\
\text { without } \\
\text { gargling }\end{array}$ & 7,40 & 6,96 & 0,44 & $-4,312$ & 0,000 & 0,05 & Meaningful \\
water & & & & & & & \\
\hline
\end{tabular}

Table 2 shows that the group without gargling water 5 minutes after consuming sweet and sticky foods experienced the most decrease in $\mathrm{pH}$ from 7.70 to 7.06 with a difference of 0.64 . The Asymp. Sig (p) value without gargling directly/0 minutes was $0.251>0.05$, thus, Ho was rejected and Ha was accepted, meaning that statistically there was no significant difference before and after consuming sweet and sticky foods without gargling directly $/ 0$ minutes, on the salivary $\mathrm{pH}$ of elementary school students, meaning that there is no effect without gargling water directly/0 minutes after consuming sweet foods and sticking to the salivary $\mathrm{pH}$ of elementary school students. The Asymp. Sig (p) value without gargling water 5 minutes after consuming sweet and sticky foods is 0.000 $<0.05$, thus, Ho is accepted and $\mathrm{Ha}$ is rejected. It statistically means that there is a significant difference in salivary $\mathrm{pH}$ before and after consuming sweet foods and attached 5 minutes later without gargling with water, meaning that there was no effect without rinsing with water 5 minutes after consuming sweet foods and attached to the salivary $\mathrm{pH}$ of SDN Puluhan students. The Asymp. Sig (p) $\mathrm{pH}$ value of saliva without rinsing with water 10 minutes after consuming sweet foods and sticking is $0.000<0.05$, thus, Ho is accepted and Ha is rejected. Statistically, it means that there is a significant difference before and after consuming sweet foods and attached 10 minutes later without rinsing with water, to the salivary $\mathrm{pH}$ of SDN Tens students. It means that there is an effect without rinsing with water, 10 minutes after consuming sweet foods and sticking to the $\mathrm{pH}$ of the saliva of SDN Puluhan students.

Table 3. Results of the Group Analysis of Gargling and without Gargling Water using the Mann Whitney Test

\begin{tabular}{lrrl}
\hline Time & Asymp.Sig & A & Information \\
\hline 0 minute & 0,000 & 0,05 & Not meaningful \\
\hline 5 minute & 0,000 & 0,05 & Meaningful \\
\hline 10 minute & 0,429 & 0,05 & Not meaningful \\
\hline
\end{tabular}

Table 3 provides information between the average salivary $\mathrm{pH}$ of the 0 -minute and 5-minute gargling group with the respondent's saliva $\mathrm{pH}$ without rinsing with water 0 minutes and 5 minutes after consuming sweet and sticky foods. The result is that the Asymp.Sig value of 0.000 is smaller than 0. 05, thus, Ho is accepted and Ha is rejected. 
Statistically, it shows that there is a significant difference between the $\mathrm{pH}$ value of the saliva of students who gargle 0 minutes and 5 minutes and the $\mathrm{pH}$ of the saliva of students who do not rinse their mouth with water for 0 minutes and 5 minutes. As for the average salivary $\mathrm{pH}$ of the 10-minute gargling group with the respondent's saliva $\mathrm{pH}$ without rinsing with water 10 minutes after consuming sweet and sticky foods. The results obtained that the Asymp. Sig value of 0.429 is greater than 0.05 , thus, Ho is rejected and $\mathrm{Ha}$ is accepted. Then, statistically, it shows that there is no significant difference between the saliva $\mathrm{pH}$ values of respondents who gargled with no gargling.

To determine the effectiveness of gargling water 0 minutes, 5 minutes and 10 minutes after consuming sweet foods and sticking to the $\mathrm{pH}$ of the respondents' saliva, the Anova test was conducted, and the results of the study, there were significant differences $(p=0.027),(p=0.000),(p=0.009)$.

Table 4. Anova Test Post Hoc Tests Tukey HSD Test Saliva $\mathrm{pH}$ Direct gargling 0 minutes, 5 minutes and 10 minutes.

\begin{tabular}{lcr}
\hline Gargling Time (I) & Gargling Time (J) & Sig \\
\hline Gargling 0 minute & Gargling 5 minutes & $.0,027$ \\
\cline { 2 - 3 } & Gargling 10 minutes & 0,000 \\
\hline Gargling 5 minutes & Gargling 0 minute & 0,027 \\
\cline { 2 - 3 } & Gargling 10 minutes & 0,009 \\
\hline Gargling 10 minutes & Gargling 0 minute & 0,000 \\
\cline { 2 - 3 } & Gargling 5 minutes & 0,009 \\
\hline
\end{tabular}

Table 4 can be seen that between gargling directly/0 minutes and 5 minutes showed a significant difference, sig $=0.027<0.05$ ), gargling 0 minutes with 10 minutes showed a difference, Sig $=0.000<0.05$. Gargling 5 minutes with 10 minutes showed a significant difference, $\mathrm{sig}=0.009<0.05$. It means direct gargling time $/ 0$ minutes is the most effective in increasing salivary $\mathrm{pH}$.

To determine the effectiveness without gargling water 0 minutes, 5 minutes and 10 minutes after consuming sweet foods and attached to the $\mathrm{pH}$ of the respondents' saliva, the Anova test was performed, and the results of the study, there were significant differences $(p=0.000),(p=0.000)$, and there was no significant difference between 5 minutes and 10 minutes $(\mathrm{p}=0.728)$.

Table 5. Saliva $\mathrm{pH}$ ANOVA test without direct gargling/0 minutes, 5 minutes and 10 minutes.

\begin{tabular}{lrr}
\hline Time Without Gragling (I) & Time Without Gargling (J) & Sig \\
\hline Without Gargling 0 minute & Without Gargling 5 \\
& minutes & $.0,000$ \\
\cline { 2 - 3 } & Without Gargling 10 \\
minutes & 0,000 \\
\hline Without Gargling 5 minutes & Without Gargling 0 & minute \\
& Without Gargling 10 \\
& minutes & 0,000 \\
\cline { 2 - 3 } & Without Gargling 0 \\
minute & 0,728 \\
\hline Without Gargling 10 minutes & Without Gargling 5 \\
& minutes & 0,000 \\
\cline { 2 - 3 } & & 0,728 \\
\hline
\end{tabular}


Table 5 shows that between no direct gargling/ 0 minutes and 5 minutes showed a significant difference $(\mathrm{sig}=0.000)$, without rinsing 0 minutes with 10 minutes showed no difference, $\operatorname{Sig}=0.000<0.05$. Without rinsing for 5 minutes with 10 nits, there was a significant difference, $\operatorname{sig}=0.728>0.05$. It means that without gargling for 5 minutes the most effect on the decrease in salivary $\mathrm{pH}$.

Gargling can clean the oral cavity from debris, prevent and reduce plaque accumulation and have a direct effect on saliva. One of the simple, inexpensive, efficient and no side effects that can be performed in maintaining oral health is to rinse with water. The results showed that gargling water immediately/0 minutes and 5 minutes after consuming sweet and sticky foods could increase the $\mathrm{pH}$ of respondents' saliva. The longer the time to rinse water, which is 10 minutes after eating sweet foods, the lower the salivary $\mathrm{pH}$.

The results of this study are in accordance with the results of research by Jannah, et al., (2016), which revealed that gargling water can remove food debris in the oral cavity, the fluorine contained in it can inhibit the demineralization process and bind to tooth enamel components, reduce the activity of microorganisms and can has a direct effect on salivary pH (Jannah, et al., 2016). Furthermore, in accordance with the results of research Amalia, et al., (2014), that there is an increase in salivary $\mathrm{pH}$ after gargling using white tea solution. Another study also stated that there was an increase in salivary $\mathrm{pH}$ after gargling with a miswak solution.

Another study that is in line with this research is the research of Wahyuningsih, \& Ramadhani, (2015), which states that gargling is one of the preventive measures for the occurrence of dental caries, which is the easiest and cheapest to apply. You should always rinse your mouth with water after every meal. It can speed up the $\mathrm{pH}$ of the saliva in the mouth back to normal, thus, it does not have time to weaken tooth enamel. Treatment/intervention time ( 0 minutes, 5 and 10) minutes for 3 groups without gargling after consuming sweet and sticky foods, the results showed that the three interventions could lower salivary $\mathrm{pH}$, and the most $\mathrm{pH}$-lowering value was without gargling 5 minutes after consuming sweet foods, that is 0.64 .

The results of this study are in accordance with research (Jannah, et al., 2016), which states that sweet and sticky foods contain carbohydrates which are the main energy source for oral bacteria that are directly involved in lowering $\mathrm{pH}$. Although the first 5-10 minutes after eating are critical times for $\mathrm{pH}$ (around 5.2-5.5), in the author's study 5-10 minutes after consuming sweet foods, there is a decrease in $\mathrm{pH}$, but the $\mathrm{pH}$ remains in an alkaline/neutral state. It may be caused by other factors, including the respondent's saliva factor.

Another study that is also in line with the results of this study is a study conducted by Sulendra, et al., (2013), which states that saliva as a host factor plays a role in the protection mechanism that maintains the normal flora of the oral cavity and tooth surface, which are bacterial cleansing, antibacterial activity, buffers, and remineralization. Saliva also has a buffer system that functions to neutralize acidic conditions that arise due to plaque formation or acidic foods and drinks.

Without gargling water for 0 minutes, 5 minutes and 10 minutes after consuming sweet and sticky foods, it can reduce the $\mathrm{pH}$ of the respondent's saliva. The results of this study are in accordance with the results of research (Suratri, et al., 2017), which states that sweet and sticky foods containing carbohydrates are the main energy source for oral bacteria and are directly involved in lowering salivary $\mathrm{pH}$. There is a relationship between the $\mathrm{pH}$ of Saliva and the habit of drinking sweet milk (sugar), and often drinking and eating sweet and sticky foods in pre-school age children in Banten Province and Yogyakarta Special Region. This is also in accordance with the research 
of Suyuti, (2012), which stated that the occurrence of caries in children's teeth was caused by the influence of eating sweet and sticky foods.

The results of the analysis used the Wilcoxon test, the average $\mathrm{pH}$ of saliva gargling with water 0 minutes after consuming sweet and sticky foods obtained the Asymp.Sig (p) value of $0.004<0.05$, thus, Ho is accepted and $\mathrm{Ha}$ is rejected. It statistically means that there is a difference or there is an effect of gargling water directly/0 minutes after consuming sweet foods and attached to the $\mathrm{pH}$ of the respondent's saliva. You should always rinse your mouth with water after every meal, so that the $\mathrm{pH}$ of the saliva in the mouth returns to normal.

The results of this study are in accordance with the results of research by A'yun, et al., (2016), that after chewing simple carbohydrate foods, gargling with water, the average $\mathrm{pH}$ of saliva after gargling will increase. The $\mathrm{pH}$ of saliva after gargling has increased from the $\mathrm{pH}$ of saliva after chewing simple carbohydrate foods. It proves that gargling vigorously over the entire surface of the mouth can remove the remnants of food debris in the oral cavity thereby reducing bacterial activity and providing a mechanical effect that can affect salivary $\mathrm{pH}$. The results of this study are also in accordance with previous research which states that you should always rinse your mouth with boiled water after every meal. It can speed up the $\mathrm{pH}$ of the saliva in the mouth back to normal, thus, it does not have time to weaken tooth enamel.

Wilcoxon test average $\mathrm{pH}$ of saliva gargling with water, 5 minutes after consuming sweet and sticky foods, the Asymp. Sig (p) value is $0.177>0.05$, thus, Ho is rejected and $\mathrm{Ha}$ is accepted. Statistically, it means that there is no significant difference or no effect of gargling water 5 minutes after consuming sweet foods and attached to the $\mathrm{pH}$ of the respondent's saliva. Although not significant, but numerically/value, there is an increase in salivary $\mathrm{pH}$ which is 0.15 from before rinsing 7.48 after gargling water to 7.63 .

The results of this study are not in accordance with research by A'yun, et al., (2016), which states that within 1-3 minutes after eating food/some types of food carbohydrates, such as sucrose and glucose which are fermented by certain bacteria will form acid so that the plaque $\mathrm{pH}$ decreases to below 5. Repeated decreases in $\mathrm{pH}$ will result in demineralization of the vulnerable tooth surface and the caries process begins.

The Asymp. Sig (p) pH value of saliva gargling with water 10 minutes after consuming sweet and sticky foods was $0.123<0.05$, thus, Ho was rejected and Ha was accepted. Statistically it means that there was no significant difference in rinsing with water, 10 minutes. after consuming sweet foods and sticking to the $\mathrm{pH}$ of saliva, meaning that there is no effect of gargling water, 10 minutes after consuming sweet foods and sticking to the $\mathrm{pH}$ of the respondent's saliva. In this group, there was a decrease in salivary $\mathrm{pH}$ of 0.18 , from 7.31 (basic) to 7.13 (alkaline). This decrease in salivary $\mathrm{pH}$ did not cause a critical $\mathrm{pH}$ state, possibly caused by other factors including salivary factors. Meanwhile, the results of this study are in accordance with research (Ismianifatun, et al., 2012), that in the mouth there is saliva (saliva) which has a buffer effect or balance. Fifteen (15) - 20 minutes after eating the salivary $\mathrm{pH}$ will return to normal.

The average $\mathrm{pH}$ of saliva without rinsing with water $(0)$ minutes after consuming sweet foods decreased by 0.13 from before rinsing with water, from 7.68 (base) to 7.55 (base). The average $\mathrm{pH}$ of respondents' saliva without rinsing with water (5) minutes after consuming sweet and sticky foods decreased by 0.64 from before rinsing with water, that was from 7.70 (base) to 7.06 (base). Means that without rinsing water/0 minutes or 5 minutes after consuming sweet and sticky foods can lower the $\mathrm{pH}$ of 
saliva, although it drops, but in this study, the $\mathrm{pH}$ was still in an alkaline state. This may be caused by the respondent's saliva, which tends to be alkaline.

The results of this study are in accordance with research (Sari, 2011), that an alkaline salivary $\mathrm{pH}$ can cause high salivary secretion in children, so that it has an impact on high saliva volume as well. One of the functions of saliva is to act as a buffer that helps neutralize the $\mathrm{pH}$ of saliva after eating, so that if the volume is high, it will balance the $\mathrm{pH}$ of the saliva and reduce the occurrence of demineralization. The average salivary $\mathrm{pH}$ of the respondents was alkaline (7.53) after brushing their teeth. It can be due to the effect of toothpaste containing sorbitol and xylitol used by respondents. Sorbitol and xylitol have been shown to increase salivary $\mathrm{pH}$. The results of this study are in accordance with research (Ismianifatun, et al., 2012), that Sorbitol has the advantage of not being easily fermented by bacteria so that it can increase remineralization and reduce dental caries and does not reduce saliva $\mathrm{pH}$ so that saliva remains stable at a certain $\mathrm{pH}$. Xylitol is also clinically proven to inhibit plaque teeth by $80 \%$, inhibits tooth enamel demineralization, salivary $\mathrm{pH}$, produces tooth enamel remineralization.

This study is also in accordance with research (Putri, et al., 2010) on 70 smokers. After chewing xylitol gum the salivary $\mathrm{pH}$ increased from 5.59 to 7.77. Another study conducted by Ismianifatun, et al., (2012), also stated that sorbitol can suppress the growth of Streptococcus mutans bacteria so that the $\mathrm{pH}$ of saliva does not decrease. Toothpaste containing sorbitol and xylitol has the property of stimulating salivary flow so as to increase the rate of salivary saliva contains bicarbonate which can increase the buffering capacity as well as the toothpaste does not reduce salivary $\mathrm{pH}$ but increases salivary $\mathrm{pH}$.

The results of this study are in accordance with the opinion of Aldiaman, et al., (2016) in brushing teeth, to be effective, brushing teeth must be considered. One of the good techniques for children is the circular/fone's technique. The results of this study are also in accordance with the study, that the average OHI-S score before brushing teeth with the fone method was 2.3 with bad criteria and after brushing teeth with the fone method it dropped to 0.9 with good criteria. It means that with a good OHIS, the $\mathrm{pH}$ of the saliva is neutral or alkaline.

The results of the Wilcoxon test results from three groups showed that there was a decrease in salivary $\mathrm{pH}$, and the most was in the group without gargling 5 minutes after consuming sweet and sticky foods, which was 0.64 followed by no rinsing with water 10 minutes after consuming sweet and sticky foods, at 0,44 . Although there was a decrease in salivary $\mathrm{pH}$, the $\mathrm{pH}$ was alkaline (7.55) and neutral (6.96). The results of this study indicate that consuming sweet and sticky foods can reduce salivary $\mathrm{pH}$.

The results of this study are not in accordance with the research of Lestari, (2016), which stated that during the first 5-10 minutes after eating, the $\mathrm{pH}$ is critical (around 5.2-5.5). After eating, especially carbohydrate foods, there will be fermentation of food glucose. The result is a compound that is acidic and makes the environment around the teeth acidic. Within a few minutes, the degree of acidity will increase or the $\mathrm{pH}$ will decrease. If the $\mathrm{pH}$ continues to decrease, it will reach a critical $\mathrm{pH}$ value. The $\mathrm{pH}$ value under normal conditions is in the range of 5,6,6 with an average of 6,8 . The presence of changes in $\mathrm{pH}$ after eating will return to normal after 20-30 minutes later.

The results of this study are in accordance with the research of Kartikasari \& Nuryanto, (2014), which stated that food/several types of dietary carbohydrates, such as sucrose and glucose which are fermented by certain bacteria will form acid so that the plaque $\mathrm{pH}$ decreases. The difference is the results of the research on decreasing the $\mathrm{pH}$ are still in an alkaline state Lestari dan Putri, (2016), research reaches below 5 within 1- 
3 minutes. Repeated decrease in $\mathrm{pH}$ will result in demineralization of vulnerable tooth surfaces and the caries process begins.

According to the research of Worotitjan, et al., (2013), that consuming cariogenic foods frequently and repeatedly will cause plaque $\mathrm{pH}$ to be below normal and cause demineralization of enamel and the formation of dental caries. In accordance with the research by Praptiningsih \& Ningtyas, (2010), that the food eaten can cause saliva to be acidic or alkaline. Consumption of sugar-containing foods and beverages between meals and at mealtimes is associated with a large increase in caries.

The results of research by Setiawan, (2012), that the $\mathrm{pH}$ of saliva 5 minutes after eating has not changed much compared to the initial $\mathrm{pH}$ before brushing teeth in the method of brushing teeth before eating. Salivary pH 15 minutes and 30 minutes after eating showed a lower $\mathrm{pH}$ change (acidic) compared to the initial $\mathrm{pH}$ before brushing teeth on the method of brushing teeth before eating.

School age children, especially elementary school children, are a group that is vulnerable to dental and oral diseases because generally at school age these children still have behaviors or habits that do not support dental health. Dental caries is a disease of the hard tissues of the teeth characterized by demineralization of the hard tissues of the teeth, followed by damage to organic matter that can cause pain to pain (panna). Cariogenic foods are foods that can cause dental caries. The nature of cariogenic foods is that they contain lots of carbohydrates, are sticky and break easily in the mouth.

The relationship between carbohydrate consumption and the occurrence of dental caries is related to the formation of plaque on the tooth surface. Plaque formed from food debris that sticks between the teeth and this plaque will eventually grow bacteria which can convert glucose into acid so that the $\mathrm{pH}$ of the oral cavity decreases to 4.5. In such circumstances, the tooth enamel structure will dissolve. Repeated consumption of carbohydrates that are too frequent causes the production of acid by bacteria to become more frequent so that the acidity of the oral cavity becomes more acidic and more enamel is dissolved.

The results of data analysis using the Mann Withney test in this study are in accordance with research (Wahyuningsih \& Ramadhani, 2015), which states that gargling is one of the preventive measures for dental caries, which is the easiest and cheapest to conduct. It is better to gargle after finished eating. It can speed up the $\mathrm{pH}$ of the saliva in the mouth back to normal, thus, it does not have time to weaken tooth enamel. Saliva has a buffer system that functions to neutralize acidic conditions that arise due to plaque formation or acidic foods and drinks. Saliva forms a mucus layer as a protective mucosa, helps inhibit plaque formation, regulates the $\mathrm{pH}$ of the oral cavity, and others.

Meanwhile, without gargling immediately (0) minutes after consuming sweet and sticky foods, it lowered the salivary $\mathrm{pH}$ by 0.13 . Without gargling water for 5 minutes, the $\mathrm{pH}$ lowers by 0.64 . This means that without gargling water, 0 minutes and 5 minutes after consuming sweet foods causes a decrease in salivary $\mathrm{pH}$.

The results of this study are in accordance with the research of Praptiningsih \& Ningtyas, (2010), which stated that at 5 minutes after consuming sweet carbohydrates it affects the electrolyte properties of saliva so that it can affect the $\mathrm{pH}$ value. The result is that the asymp Sig value is $0.429>0.05$ so Ho is rejected and Ha is accepted, these results indicate that there is no significant difference in effectiveness between the salivary $\mathrm{pH}$ value of respondents who rinsed with no gargling, which both lowered the $\mathrm{pH}$ of saliva, those who rinsed their mouths decreased. 0.18 , without gargling, the $\mathrm{pH}$ decrease was 0.44 . 
The results of this study are in accordance with research by Praptiningsih \& Ningtyas, (2010), that changes in the degree of acidity tend to increase 15 minutes after eating and then the acidity value will decrease. It can happen because each intake of consumption can change the state of acidity in the oral cavity,

Between the two brushing times, namely after eating and before going to bed, it is recommended that you always rinse your mouth with water after every meal. It can accelerate the $\mathrm{pH}$ of saliva in the mouth to return to normal, so that it does not have time to weaken tooth enamel." The results of this study are in accordance with dental research (Wahyuningsih \& Ramadhani, 2015), which states that after chewing simple carbohydrate foods, then gargling with mineral water, then the average $\mathrm{pH}$ of saliva after gargling will increase. The average $\mathrm{pH}$ of saliva after gargling has increased from the $\mathrm{pH}$ of saliva after chewing simple carbohydrate foods. It proves that gargling vigorously over the entire surface of the mouth can remove the remnants of food debris in the oral cavity thereby reducing bacterial activity and providing a mechanical effect that can affect the saliva.

The results of data analysis using the Tukey HSD test in this study are in accordance with research (Setiawati, 2012), which asserted that the decrease in pH can be caused by salivary factors. A decrease in the rate of salivary secretion will cause a decrease in salivary $\mathrm{pH}$. The results of this study are also in accordance with the research of Praptiningsih \& Ningtyas, (2010), which stated that cariogenic foods are foods that can cause dental caries. The nature of cariogenic foods is that they contain lots of carbohydrates, are sticky and break easily in the mouth. The relationship between carbohydrate consumption and the occurrence of dental caries is related to the formation of plaque on the tooth surface. Plaque is formed from food debris that sticks between the teeth and this plaque will eventually grow bacteria that can convert glucose into acid so that the $\mathrm{pH}$ of the oral cavity decreases to 4.5. In such circumstances, the tooth enamel structure will dissolve. Repeated consumption of carbohydrates that are too frequent causes the production of acid by bacteria to become more frequent so that the acidity of the oral cavity becomes more acidic and more enamel is dissolved.

The results of this study are not in accordance with the research of Oktarianda, (2011), that after eating, especially carbohydrate foods, there will be fermentation of food glucose. The result is an acidic compound and creates an acidic environment around the teeth. Within a few minutes the degree of acidity will increase or the $\mathrm{pH}$ will decrease. If it continues, the decrease in the $\mathrm{pH}$ value will reach a critical $\mathrm{pH}$ value, which is a $\mathrm{pH}$ value that can trigger decalcification (loss of calcium salts) in tooth enamel. The presence of changes in $\mathrm{pH}$ after eating will return to normal after 20-30 minutes later. During the first 5-10 minutes after a meal is a critical time for $\mathrm{pH}$ (approximately 5.2-5.5). In this study, although without gargling, there was a decrease in salivary $\mathrm{pH}$ after consuming sweet foods, but the respondent's $\mathrm{pH}$ was neutral to alkaline. This might be due to saliva factors and the effect of using toothpaste when brushing teeth before the intervention. Limitations in this study include that researcher has not been able to fully control the gargling behavior of each respondent.

\section{CONCLUSION}

The most effective gargling time on the salivary $\mathrm{pH}$ of elementary school students after consuming sweet and sticky foods is gargling immediately/0 minutes. The time without gargling water that has the most effect on saliva $\mathrm{pH}$ in elementary school students after consuming sweet and sticky foods is 5 minutes. 
Sulastri, S., Sulistiyani, H., \& Khasanah, F. (2021). Saliva pH Between Gargling and Without Gargling Water after Consuming Sweet and Sticky Foods. JURNAL INFO KESEHATAN, 19(1), 85-96. https://doi.org/10.31965/infokes.Vol19/ss1.466

\section{REFERENCES}

Aldiaman, H., Adhani, R., \& Adenan, A. (2016). Efektivitas Menyikat Gigi Dengan Metode Fone Terhadap Indeks Kebersihan Rongga Mulut. Dentino: Jurnal Kedokteran Gigi, 1(2), 12-16.

Amalia, N., Kaidah, S., Widodo. (2014). Perbandingan Efektifitas Berkumur Larutan The Putih (Camellia sinensisL.) Seduh Konsentrasi 100 \% Dengan 50 \% Dalam Meningkatkan pH Saliva. Dentino Jurnal Kedokteran Gigi, 2 (1), 29-33.

A'yun, Q., Hendrartini, J., \& Supartinah, A. (2016). Pengaruh keadaan rongga mulut, perilaku ibu, dan lingkungan terhadap risiko karies pada anak. Majalah Kedokteran Gigi Indonesia, 2(2), 86-94. doi: https://doi.org/10.22146/majkedgiind.11267

Haryani, W., Siregar, I., \& Ratnaningtyas, L. A. (2016). Buah mentimun dan tomat meningkatkan derajat keasaman $(\mathrm{pH})$ saliva dalam rongga mulut. Jurnal Riset Kesehatan, 5(1), 21-24.

Ismi'anifatun, D., Kristiyawati, S. P., \& Solechan, A. (2012). Perbedaan Ph Saliva Sebelum Dan Sesudah Menggosok Gigi Dengan Pasta Gigi Yang Mengandung Sorbitol Dan Xylitol Pada Pasien Diabetes Mellitus Di Rsud Tugurejo Semarang. Karya Ilmiah, 1.

Jannah, M., Hidayati, H., \& Afriwardi, A. (2016). Perbedaan pH Saliva Antara Berkumur dan Tanpa Berkumur Air Putih Setelah Mengunyah Makanan Berkarbohidrat Sederhana. Andalas Dental Journal,4(1), 67-77. doi: https://doi.org/10.25077/adj.v4i1.50

Kartikasari, H. Y., \& Nuryanto, N. (2014). Hubungan Kejadian Karies Gigi dengan Konsumsi Makanan Kariogenik dan Status Gizi pada Anak Sekolah Dasar (Studi pada Anak Kelas III dan IV SDN Kadipaten I dan II Bojonegoro). Journal of nutrition college, 3(3), 414-421.doi: https://doi.org/10.14710/jnc.v3i3.6605

Kementerian Kesehatan, R. I. (2018). Laporan hasil riset kesehatan dasar (Riskesdas) Indonesia tahun 2018. Jakarta: Badan Penelitian dan Pengembangan Kesehatan, Kementerian Kesehatan Republik Indonesia.

Kusumasari, N. (2012). Pengaruh larutan kumur ekstrak siwak (salvadora persica) terhadap $\mathrm{pH}$ saliva. Skripsi. Program Studi Pendidikan Sarjana Kedokteran, Fakultas Kedokteran Universitas Diponegoro.

Lestari, S., \& Putri, T. A. A. (2016). Hubungan antara kebiasaan konsumsi makanan manis dengan karies gigi anak usia sekolah (The relation between habitual consumption of sweet foods with tooth caries of school age children). Jurnal PDGI, 65(2), 55-59. from http://jurnal.pdgi.or.id/index.php/jpdgi/article/view/144

Notoatmodjo, S. (2012). Metodologi Penelitian Kesehatan. Jakarta: Rineka Cipta.

Oktarianda, B. (2011). Hubungan waktu, tekhnik menggosok gigi dan jenis makanan yang dikonsumsi dengan kejadian karies gigi pada murid SDN 66 Payakumbuh di wilayah kerja Puskesmas Lampasi Payakumbuh tahun 2011. Skripsi. Program Studi Ilmu Kesehatan Masyarakat, Fakultas Kedokteran, Universitas Andalas.

Putri, M. H., Herijulianti, E., \& Nurjannah, N. (2010). Ilmu Pencegahan Penyakit Jaringan Keras dan Jaringan Pendukung Gigi. Jakarta: EGC.

Praptiningsih, R. S., \& Ningtyas, E. A. E. (2010). Pengaruh metode menggosok gigi sebelum makan terhadap kuantitas bakteri dan $\mathrm{pH}$ saliva. Majalah Ilmiah Sultan Agung, 48(123), 55-62. 
Sari, N. N. G. (2011). Permen Karet Xylitol yang Dikunyah Selama Menit Meningkatkan dan Mempertahankan pH Saliva Perokok Selama 3 Jam. Tesis. Program Studi Ilmu Biomedik, Program Pascasarjana Universitas Udayana.

Sulendra, K.T., Fatmawati, D. W. A., \& Nugroho A. (2013). Hubungan pH dan Viskositas Saliva terhadap Indeks DMF-T pada Siswa-siswi Sekolah Dasar Baletbaru I dan Baletbaru II Sukowono Jember. Artikel Ilmiah Penelitian Mahasiswa 2013. Fakultas Kedokteran Gigi, Universitas Jember.

Suratri, M. A. L, Jovina T. A \& Notohartojo, I. T. (2017). Pengaruh (pH) saliva terhadap terjadinya karies gigi pada anak usia prasekolah. Indonesian Bulletin of Health Research, 45(4), 241-248.

Suyuti, M. (2012). Pengaruh makanan serba manis dan lengket terhadap terjadinya karies gigi pada anak usia 9-10 tahun di SD Negeri Monginsidi II Makassar. Media Kesehatan Gigi, 2, 14.

Setiawati, F. (2012). Peran Pola Pemberian Air Susu Ibu (ASI) dalam Pencegahan Early Childhood Carries (ECC) di DKI Jakarta. Disertasi. Fakultas Kedokteran Gigi, Program Doktor Ilmu Kedokteran Gigi, Universitas Indonesia.

Wahyuningsih, M., \& Ramadhani, R. S. (2015). Bahaya Langsung Menyikat Gigi Setelah Makan. CNN Indonesia.

Worotitjan, I., Mintjelungan, C. N., \& Gunawan, P. (2013). Pengalaman karies gigi serta pola makan dan minum pada anak Sekolah Dasar di desa kiawa kecamatan kawangkoan utara. e-GiGi,l(1), 59-68. doi: https://doi.org/10.35790/eg.1.1.2013.1931 